\title{
Kebijakan Birokrasi dalam Upaya Pelayanan Publik Berkualitas
}

\author{
Kisno Hadi \\ Universitas Palangkaraya \\ e-mail:kisnohadi@yahoo.co.id
}

Qualified bureaucracy public services are very much needed in the new global trend. Every local government has to respond it and take necessary actions innovatively. This research explores about how to create qualified bureaucracy public services, and how is the best practices of bureaucracy public services in accordance with regional society. To elaborate on the issues this research maps out bureaucracy reform which has to be done by regional government, and asserts an example about the process of qualified bureaucracy public services in a smallest unit in the government structure. This research reveals that to create qualified bureaucracy public services need strong commitment of regional leaders and their stakeholders through among others: reorientation of service mission; changing service culture; creation of service based education; choosing service culture based political leaders; strengthening civil society control.

Keywords: bureaucracy, qualified public services, reform, strong commitment.

\section{Pendahuluan}

Qaat menjabat sebagai Menteri Dalam

Negeri RI, Mohammad Ma'ruf pernah mengetengahkan pendapatnya mengenai kualitas pelayanan publik oleh aparatur birokrasi, beliau mengatakan bahwa "salah satu indikator dalam membangun kepemerintahan yang lebih baik (good governance) adalah meningkatnya kualitas pelayanan publik, untuk itu perlu terus menerus didorong upaya peningkatan kapasitas dan kompetensi, terutama pada setiap unit pelayanan" (Ma'ruf, 2006). Atas asumsi Ma'ruf itu, penulis menjadi berpikir bahwa sebuah pelayanan publik yang baik bahkan berkualitas mesti dimulai dari unit-unit pelayanan terkecil pemerintah daerah, seperti RT, RW, desa dan kelurahan hingga kecamatan.

Baik dan berkualitasnya pelayanan di unit-unit tersebut bakal membawa dampak positif bagi unit pelayanan di atasnya. Dalam kegiatan berpemerintahan sehari-hari yang diutamakan adalah pelayanan. Sehingga pelayanan merupakan hal penting yang mesti menjadi perhatian serius setiap lembaga birokrasi. Ini senada seperti dikatakan Ryass Rasyid bahwa prinsip kegiatan berpemerintahan dilakukan tidak lain karena merujuk kepada misi pemerintahan itu sendiri, yakni pelayanan, pemberdayaan dan pembangunan (Rasyid, 2007). Artinya, setelah misi pelayanan membuahkan hasil maksimal, dengan sendirinya misi pemberdayaan dan pembangunan akan tercapai.

Dalam tataran pemerintah daerah, fungsi pelayanan tidak bisa dihindari karena sudah menjadi kewajiban pemerintah daerah di mana pemberian pelayanan publik kepada masyarakat adalah salah satu urusan pemerintahan yang menjadikan pemerintah daerah bisa disebut sebagai 
sebuah entitas pemerintahan. Ini merujuk pada konsepsi Bappenas bahwa secara esensial, pelaksanaan otonomi daerah mendesentralisasikan tujuh (7) urusan yang menjadi elemen dasar yang membentuk pemerintah daerah sebagai sebuah entitas pemerintahan, yakni urusan pemerintahan, kelembagaan, personil, perwakilan daerah, keuangan daerah, pelayanan publik dan pengawasan (Bappenas, 2007: 4). Karena menjadi salah satu entitas pemerintahan, penyelenggaraan pelayanan publik yang berkualitas sangat dibutuhkan masyarakat daerah karena paradigma pembangunan telah menuntut hal itu. Pelayanan publik yang berkualitas sudah menjadi trend global.

Kondisi demikian mendorong hampir semua pemerintah daerah di Indonesia membuat terobosan-terobosan baru dalam meningkatkan kualitas pelayanan publik. Tambah lagi, trend yang tidak kalah penting adalah pemberian reward oleh pemerintah pusat kepada pemerintah daerah bila berhasil menciptakan iklim birokrasi yang berkualitas. Di tataran lokal, para Kepala Daerah juga bersaing memberi reward kepada aparat birokrasinya apabila mampu menciptakan pelayanan birokrasi yang baik dan bermutu di lembaga-lembaga pemerintah daerah.

Dalam kerangka otonomi daerah seperti yang diatur UU No. 32/2004, lembaga birokrasi yang paling dekat dengan masyarakat dan paling mudah dijangkau layanannya adalah lembaga birokrasi di daerah (kabupaten/kota), sebab itu pelayanan birokrasi berkualitas mesti dilakukan dari daerah dulu karena menyangkut kepentingan keseharian masyarakat. Bila birokrasi pelayanan publik di daerah dinilai baik oleh masyarakat, barangkali akan memberi pencitraan secara positif bagi lembaga birokrasi secara keseluruhan hingga ke tataran pusat pemerintahan.

Bercakap-cakap tentang lembaga birokrasi pelayanan publik di daerah yang paling sering memberi layanan kepada masyarakat, sudah pasti menyangkut unit birokrasi terkecil, yakni kecamatan, kelurahan dan desa. Kecamatan, kelurahan dan desa memberi segala hal layanan yang menyangkut kebutuhan-kebutuhan keseharian masyarakat, seperti pelayanan pembuatan KTP, pembuatan Kartu Keluarga $(\mathrm{KK})$, pembuatan pengantar Akte Kelahiran, pembuatan Akta Catatan Sipil, SPT (Surat Pernyataan Tanah), pembuatan Akte Jual Beli Tanah, pembuatan Surat Keterangan Mutasi Penduduk, pembuatan Rekomendasi Izin Mendirikan Bangunan (IMB), dan lain-lain.

Atas asumsi tersebut di atas, tulisan ini hendak mengurai mengenai (1) bagaimana menciptakan birokrasi pelayanan publik berkualitas; dan (2) seperti apa praktek birokrasi pelayanan publik yang baik dan berkualitas dimata masyarakat di daerah? Untuk menjawab pertanyaan itu, melalui tulisan ini penulis (1) memetakan perihal reformasi birokrasi yang mesti dilakukan pemerintah daerah; dan (2) mengurai contoh kecil mengenai proses pelayanan publik berkualitas di sebuah unit pelayanan terkecil dalam struktur pemerintahan daerah di Kecamatan Kahayan Hilir, Kabupaten Pulang Pisau, Provinsi Kalimantan Tengah.

\section{Kajian Pustaka}

Secara nasional, jumlah pegawai negeri yang menopang aktivitas-aktivitas birokrasi di Indonesia ternyata telah mencapai 4 juta pegawai (BAKN, 2005: 33). Jumlah tersebut terus bertambah seiring penerimaan pegawai negeri di semua daerah di Indonesia sejak tahun 2005 hingga 2009 sekarang. Namun jumlah sebesar itu ternyata belum optimal 
Kebijakan Birokrasi Pelayanan Publik Berkualitas; Kisno Hadi

memberikan pelayanan publik terbaik kepada masyarakat. Efisiensi dan efektifitas kinerja birokrasi yang menjadi slogan hampir setiap pemerintah daerah ternyata belum terwujud sesuai program. Melihat kondisi kinerja para birokrat seperti itu, salah satu langkah yang sering dilakukan oleh pejabat politik baru yang menduduki kepemimpinan di level pemerintahan daerah adalah "rasionalisasi", yakni memfokuskan kebijakan pada perombakan besar-besaran terhadap formasi birokrat. Mutasi juga dilakukan terhadap aparatur birokrat yang dinilai memiliki kinerja kurang baik. Langkah tersebut tentu saja memicu ketegangan hubungan antara pemimpin pemerintah daerah yang dipegang pejabat politik dengan aparat birokrasi dan masyarakat.

Ketegangan bisa terjadi karena pejabat politik yang baru ternyata lebih suka memasukkan pejabat birokrat yang menjadi simpatisannya ke dalam birokrasi di bawahnya ketimbang mencari pejabat birokrat terbaik di lingkungan kerja yang ada. Ini sering terjadi di beberapa daerah kabupaten/kota dalam hal pemilihan Sekretaris Daerah (Sekda), dimana Sekda baru sering diambil dari pejabat dari luar daerah ketimbang mencari pejabat yang ada di dalam lingkungan daerah itu sendiri. Tidak hanya ketegangan, kebijakan tersebut sering berbuah resistensi pejabat birokrat yang merasa sudah layak menduduki jabatan tersebut. Sialnya, resistensi tidak hanya datang dari pejabat di lingkup birokrasi yang merasa dirugikan, melainkan juga datang dari sekelompok masyarakat yang juga tidak setuju karena merasa Sekda tersebut bukan representasi kelompok masyarakat di daerah bersangkutan. Oleh sebab itu, slogan reformasi birokrasi oleh beberapa daerah ternyata tidak lebih dari sekadar "menyingkirkan" peran aparat birokrat yang tidak disukai untuk mengo- kohkan peran aparat birokrat yang disukai. Akibatnya birokrasi tidak pernah dapat bekerja secara optimal dan profe-sional. Di sisi lain, aparat birokrat yang disokong elitelit politik dari luar birokrasi ternyata juga berusaha melakukan kolusi dan pendekatan secara pribadi kepada pejabat politik yang baru itu untuk menga-mankan jabatan serta yang menginginkan jabatan tertentu. Di sinilah sebenarnya semangat melakukan reformasi birokrasi pelayanan publik diuji besar-besaran, di mana pemegang kendalinya adalah pemimpin politik di level pemerintahan bersangkutan. Namun kebanyakan kasus di lapangan menunjukkan, bahwa para pemimpin politik di daerah sering mengabaikan kepentingan rakyat yang menghendaki adanya perubahan dalam birokrasi pelayanan publik yang disebabkan oleh kuatnya pengaruh aparat birokrat dan elit politik tertentu yang menginginkan jabatan. Kepentingan rakyat kerapkali kalah karena lobi-lobi yang sering dibumbui dengan segepok uang sogokan.

Sejarah menunjukkan bahwa birokrasi Indonesia sudah lama dijadikan alat mobilisasi politik bagi elit-elit politik dari partai penguasa dan kepemimpinan politik baik nasional maupun lokal untuk melang-gengkan kekuasaan. Karenanya di era reformasi sistem politik dan reformasi sistem pemerintahan sekarang, penggantian pejabat politik di level nasional maupun daerah yang dimotori oleh partai politik baru, dengan minimnya jaringan birokrasi, pasti selalu mengalami resistensi yang tinggi dari kalangan birokrat. Itu karena birokrasi sudah lama terbiasa menjalin hubungan kerja dengan kepemimpinan dari partai politik lama yang memiliki jaringan kuat di dalam tubuh birokrasi, sementara kepemimpinan dari partai politik baru cenderung sebagai "tamu" baru yang masih perlu waktu untuk bersosialisasi dengan pejabat birokrat. Bahkan hingga ke tataran 
unit terkecil lembaga birokrat seperti kecamatan, pengelolaan kebijakan birokrasi oleh pemimpin politik baru sering berbenturan dengan kepentingan di dalam tubuh lembaga birokrasi itu sendiri, sehingga kalau dalam suatu level pemerintahan kepemimpinannya dipegang elit baru dari partai politik baru, reformasi birokrasi kebanyakan menjadi program yang sulit dilakukan.

Dalam banyak kasus, bila kepemimpinan politik berasal dari partai politik lama, apalagi pemimpin politiknya berasal dari dalam lembaga birokrat itu sendiri, maka program kebijakan birokrasi tidak mendapat resistensi yang serius dari aparat birokrat. Namun bila pemimpin politiknya orang baru dan dari partai politik baru yang minim jaringan dalam lembaga birokrat, program kebijakannya sering mendapat resistensi yang cukup serius, yakni dalam bentuk ketidakseriusan menjalankan program kebijakan, kalaupun kebijakan dilaksanakan maka mesti ada kompensasi memadai yang diterima oleh aparat birokrat yang mengerjakannya, yakni tidak jauh-jauh dalam bentuk program proyek.

Sebab itu mesti ada inovasi oleh pejabat politik yang baru untuk memangkas jurang antara kepentingan lembaga dan aparat birokrasi dengan kepentingan kebijakan pejabat politik yang baru. Kondisi tersebut tidak dapat dihindari mengingat kepemimpinan politik pemerintahan di era desentralisasi politik dan pemerintahan sekarang tidak menutup kemungkinan hanya berlaku selama 5 tahun, terpilihnya pemimpin politik yang baru dalam 5 tahun berikutnya membuat kebijakan politik yang dimotori pejabat politik dengan lembaga birokrasi sebagai penggeraknya juga berubah. Mengingat perubahan dari dalam yang tidak bisa diharapkan, maka harus diciptakan juga pendekatan struktural yang mampu mengubah budaya birokrasi.
Pendekatan struktural di sini mesti berawal dari pemimpin politik dalam level pemerintahan bersangkutan, sebab pemimpin tersebut adalah pemegang kunci melakukan perubahan. Namun perubahan budaya organisasi pemerintahan secara eksternal diharapkan tidak hanya berorientasi pada program rasionalisasi birokrasi yang sering berbuah ketegangan dan resistensi dari aparat birokrasi dan masyarakat, tetapi mesti diarahkan untuk menciptakan budaya baru birokrasi yang lebih profesional, terbuka, jeli dan tanggap dengan kebutuhan masyarakat, sehingga implementasi-implementasi kebijakan tidak mendapat resistensi yang berarti.

Bagaimana caranya menciptakan pemimpin politik yang mampu mereorientasi serta mempengaruhi reformasi birokrasi pelayanan publik sehingga programnya dapat berjalan dengan baik untuk sepenuhnya melayani kepentingan masyarakat. Bagi penulis terdapat beberapa hal yang menjadi kebutuhan untuk mewujudkan itu.

Pertama, tidak dapat ditawar lagi bahwa aparat birokrasi harus responsif terhadap dinamika ekonomi, sosial, budaya, dan politik yang bergerak di tataran masyarakat daerah. Selama ini, kecenderungan birokrasi masih mewarisi paradigma "memerintah" dan "dilayani" serta menganggap suatu jabatan publik adalah status sosial yang membedakannya dengan warga biasa. Bahasa Hans Antlov menyebutnya "masih terpaku pada cara kerja serta perilaku lama" (Antlov, 2004). Padahal bila orientasi "memerintah" dan "dilayani" itu direorientasi menjadi "melayani", maka konsekuensi sebuah jabatan publik adalah sebagai "pelayan" masyarakat yang justru menjadikan sang pejabat itu berdiri setara dengan masyarakat untuk melayani kepentingankepentingan masyarakat. Hakekatnya tatkala banyak aparatur birokrat berkom- 
Kebijakan Birokrasi Pelayanan Publik Berkualitas; Kisno Hadi

petisi hendak menjadi pejabat, maka sesungguhnya mereka berkompetisi untuk menjadi "pelayan-pelayan" masyarakat. Sistem pemerintahan yang diciptakan melalui beberapa produk UU harus mampu mereorientasi tradisi berpikir dan bekerjanya aparatur pemerintah agar bisa menjadi "pelayan" yang baik dalam tata kelola berpemerintahan. Tradisi yang berlaku, yakni birokrasi yang dilayani oleh masyarakat harus ditinggal dengan adanya produk UU tersebut. UU itu harus mampu mengatur lembaga birokrasi dan aparaturnya supaya menjadi "pelayan", bukan "dilayani". Karenanya, hal pertama yang mesti dibenahi dalam hal ini adalah pengaturan produk UU yang tidak saja sekadar memuat penyelenggara negara yang "bersih dan bebas dari KKN" seperti UU No. 28/1999, melainkan juga harus bisa menciptakan paradigma penyelenggara negara dan aparatur birokrasi sebagai "pelayan" masyarakat.

Kedua, mengingat melayani dan memenuhi kepentingan-kepentingan masyarakat dengan sebaik-baiknya belumlah menjadi semangat dan kultur aparatur birokrasi pemerintah hingga di daerah-daerah. Dengan demikian, upaya menciptakan kultur itu harus segera dimulai dari pemimpin birokrasi, yakni pemimpin politik pemerintahan dalam suatu daerah. Artinya pemimpin politik yang berkomitmen mereformasi birokrasi harus mengambil inisiatif menciptakan kultur itu dari dirinya sendiri. Kondisi tersebut membuat kita berpikir bahwa jiwa pelayan mesti dimiliki oleh pucuk pimpinan lembaga birokrat. Sebab itu, harus ada ketegasan pimpinan birokrasi daerah, misalnya menggunakan sebuah Perda, untuk mengatur bahwa aparat birokrat harus mengubah kultur yang selama ini melekat pada diri mereka, dengan kulturkultur baru yang lebih mementingkan kepentingan masyarakat. Aturan itu mesti juga menekankan jiwa kepelayanan aparat birokrasi dalam pelayanan publik dan mesti ada sanksi bila ada yang melanggar. Osborne dan Geabler menyebut bahwa upaya peningkatan pelayanan publik oleh birokrasi pemerintah perlu dilakukan karena disadari pemerintah itu milik rakyat, bukan rakyat milik kekuasaan pemerintah (Syafiie dkk, 1999), sehingga pemaknaan bahwa pemerintah atau birokrasi itu ada karena adanya masyarakat, yang tujuannya untuk melayani kepentingan masyarakat bisa melekat dalam setiap diri aparatur birokrat.

Ketiga, hingga sejauh ini tidak dapat dipungkiri bahwa masyarakat masih menganggap keberadaan birokrasi pelayanan publik bukan untuk mempermudah urusan tetapi justru menjadi penghambat bagi layanan yang harus segera diterima. Sebab itu, dalam diri para aparat birokrasi mesti ditanam budaya "rasa malu", bahwa sebagai aparat birokrat selama ini mereka adalah "penghambat kepentingan masyarakat", tempat layanan bisa lancar apabila masyarakat menyodorkan sejumlah "uang pelicin" yang di sejumlah daerah disebut dengan istilah "uang rokok", "uang pulsa", "uang administrasi" atau juga "uang ucapan terima kasih". Agar tidak lagi disebut sebagai penghambat, maka aparat birokrat mesti dipicu untuk memberi layanan yang baik dan berkualitas kepada masyarakat sehingga dari yang awalnya disebut sebagai "penghambat" bisa bergeser menjadi "pelayan yang baik". Untuk menanamkan rasa malu itu tiada jalan lain selain melalui lembaga pendidikan. Selain pendidikan formal dari taman kanak-kanak hingga perguruan tinggi, dalam lembaga pendidikan penunjang profesi seperti lembaga diklat juga harus memasukkan gagasan itu ke dalam hati dan pikiran aparat birokrasi. Salah satu yang dilupakan dalam pem- 
belajaran untuk mendidik calon birokrat selama ini adalah penanaman "budi pekerti luhur" seperti budaya kejujuran, budaya kebaikan, budaya malu, budaya anti korupsi, budaya anti peminta-minta, dan lainlain. Bila ternyata budaya penghambat itu tetap berpraktik, maka mesti ada sanksi moral yang berikan kepada pelakunya. Dalam kurikulum pendidikan formal juga mesti ditanam bahwa menjadi birokrat bukanlah profesi dan lapangan pekerjaan melainkan sebagai aparatur negara yang hakekatnya adalah melayani kepentingan masyarakat. Ini tentu saja berbeda dari konsep pendidikan sekarang yang lebih berorientasi pada mendidik orang untuk menjadi "pamong", sehingga tidak mengherankan banyak lahan ladang, sawah dan kebun di desa-desa ditinggal oleh pemiliknya karena mereka memilih menjadi pegawai negeri.

Keempat, untuk mendorong perubahan budaya aparatur birokrasi ke arah yang lebih baik, lebih profesional, lebih tanggap terhadap kebutuhan masyarakat, serta lebih memperhatikan etika-etika yang berlaku dalam masyarakat modern, bahkan juga mampu menekan adanya kepentingankepentingan politik sesaat dari aparatur birokrat yang menginginkan jabatan maupun kepentingan tokoh partai politik yang berkuasa, maka dibutuhkan figur kepemimpinan pemerintahan yang memiliki integritas kuat, memiliki karakter kuat, memiliki komitmen terhadap agenda reformasi birokrasi serta berorientasi kepada kepentingan masyarakat luas. Figur kepemimpinan semacam itu dipercaya dapat membidani lahirnya budaya baru dalam jajaran birokrasi di daerah-daerah. Atas kepemimpinan birokrasi semacam itu, diharapkan aparat-aparat birokrasi yang nakal tidak lagi mampu melobby untuk memperoleh jabatan tertentu. Secara kelembagaan birokrasi tidak akan lagi menjadi mesin partai politik atau kepentingan pihak-pihak tertentu tetapi lebih sebagai sistem organisasi pemerintah yang profesional. Untuk mewujudkan kepemimpinan politik dan pemerintahan semacam itu, harus ada komitmen segenap pihak mulai partai politik, masyarakat politik, masyarakat ekonomi, bahkan hingga aparat di dalam tubuh birokrasi di daerah. Artinya, tatkala ada pemilihan kepala daerah yang bakal menjadi pemimpin lembaga birokrasi di daerah tersebut, mereka harus mencalonkan figur yang betul-betul mumpuni dan memiliki integritas yang baik. Para elit politik di daerah diharapkan tidak sekadar berusaha menanamkan kepentingan partai politik di dalam birokrasi, tetapi harus memulai iklim baru rekruitmen calon kepala daerah yang lebih terbuka. Masyarakat politik, masyarakat ekonomi bahkan aparatur birokrasi di daerah mesti jeli, tanggap dan selalu dinamis dalam merespons dinamika perubahan. Walaupun misalnya terjadi perubahan kekuasaan dan kepemimpinan politik secara berkelanjutan setiap 5 tahun, namun tugas utama aparat birokrasi, hubungan aparat birokrasi dengan masyarakat politik, hubungan aparat birokrasi dengan partai politik maupun hubungannya dengan masyarakat ekonomi dalam rangka memberi pelayanan terbaik kepada publik mestinya tidak pernah berubah, melainkan tetap stabil. Intinya di sini berawal dari perekrutan pemimpin politik dan pemerintahan yang memiliki kredibelitas dan kapasitas, yang bila ia terpilih bakal menjadi pemimpin birokrasi yang tangguh daan bertanggungjawab serta memperhatikan kebutuhan masyarakat.

Bagaimanapun, persoalan pengelolaan pembangunan daerah akan terkendala bila aktor yang bekerja dalam lembaga pemerintah tidak peka terhadap kebutuhan 
Kebijakan Birokrasi Pelayanan Publik Berkualitas; Kisno Hadi

masyarakat. Berbagai investasi di daerah tidak akan terdorong maju bila pelayanan yang diberikan tidak maksimal, tepat dan akurat. Kehadiran investasi merupakan kemutlakan dalam upaya mempercepat pertumbuhan ekonomi masyarakat daerah, karena di dalamnya pengembangan sektor riil yang menjadi tumpuan perekonomian masyarakat bisa berkembang dengan baik. Kalau birokrasi tidak memberi pelayanan yang baik dalam rangka mendorong lajunya investasi, baik investasi oleh penduduk setempat maupun investor dari luar, akan berimplikasi pada kelambanan pertumbuhan ekonomi daerah, masyarakat miskin dan pengangguran niscaya akan semakin bertambah.

Sekarang persoalan investasi dan pengembangan daerah telah ada di tangan pemerintah daerah dan masyarakat daerah, selanjutnya tergantung komitmen masingmasing pihak yang berkompeten di daerah tersebut untuk menjalaninya. Persoalan reformasi birokrasi pelayanan publik di daerah sangat erat kaitannya dengan pengelolaan pemerintahan, di mana peran pemimpin daerah turut signifikan mempengaruhi. Rose-Ackerman menyebut, bahwa reformasi terkadang terjadi hanya karena ada pemimpin karismatik mempunyai komitmen untuk memperjuangkan reformasi. Pemimpin yang kuat dapat memberi inspirasi kepada penduduk (dan aparat birokrat) untuk menerima reformasi besar-besaran yang tidak dapat dilakukan oleh orang lain karena tidak memiliki kepribadian yang setara (Rose-Ackerman, 2006).

Kelima, kontrol dari masyarakat lokal haruslah paralel dengan agenda reformasi birokrasi pelayanan publik di daerah, karena tanpa kontrol yang baik dan ketat dari masyarakat agenda reformasi birokrasi pelayanan publik hanya menjadi sebuah imajinasi. Kontrol di sini bisa dilakukan melalui publikasi media massa, advokasi melalui kelembagaan masyarakat adat, relasi yang baik antara tokoh masyarakat dengan pemimpin birokrasi, pemboikotan peralatan kantor (ATK) dari masyarakat ekonomi dan lain-lain. Kekuatan kontrol ini sangat penting untuk mengawal kebijakankebijakan publik serta merespon implementasinya di lapangan. Misalkan dalam proses pelayanan publik di kantor kecamatan terdapat hal yang dinilai merugikan, maka kesalahan itu dapat diproses melalui pemimpinnya dengan meminta konfirmasi atau publikasi di media massa. Peranan lembaga legislatif daerah juga mesti dimaksimalkan dalam rangka kontrol dan pengawasan terhadap kinerja aparatur birokrasi. Di lain sisi, peranan Lembaga Ombudsman Daerah juga mesti dimaksimalkan. Hingga sejauh ini belum ada titik terang sejauhmana peran Lembaga Ombudsman Nasional dan Daerah yang katanya untuk mengontrol dan mengawasi kinerja aparatur birokrasi di sektor pelayanan publik memberi dampak positif terhadap kualitas pelayanan birokrasi. Sebab itu peran lembaga ini mesti ditinjau ulang karena terjadi ketumpang-tindihan dengan peran lembaga legislatif serta peran Badan Pengawas Daerah (Banwasda) yang juga sama-sama bekerja mengontrol dan mengawasi kinerja birokrasi.

Dan Keenam, masalah Korupsi, Kolusi dan Nepotisme (KKN). Persoalan birokrasi pelayanan publik tidak bisa lepas dari persoalan KKN, baik KKN untuk mendapatkan jabatan tertentu dalam kelembagaan birokrasi maupun KKN antara aparat birokrat dengan masyarakat yang dilayani yang katanya untuk memperlancar proses pelayanan. Untuk menghindari KKN di sektor pelayanan publik ini, di Maroko menurut Maddick hampir tidak ada kar- 
yawan dalam sistem pemerintahan daerah, tidak ada bendara, tidak ada sekretaris, tidak ada teknisi, yang ada adalah struktur pemerintah daerah yang kecil dengan jumlah pegawai yang sangat sedikit, sehingga dari keterbatasan pegawai tersebut dapat dibentuk kandidat yang memenuhi syarat yang dapat dilatih untuk menjadi pegawai profesional. Kantor kota praja tidak dibuka sampai tengah hari sehingga memungkinkan pegawai dapat bekerja sambilan di luar atau di sektor lain sehingga pegawai mendapat penghasilan tambahan. Kebijakan mempekerjakan pegawai sebanyak-banyaknya di sektor pelayanan publik dengan tujuan mengurangi pengangguran bukanlah kebijakan yang bijak (Maddick, 2004).

Dengan terlalu banyak orang yang bekerja di sektor pelayanan publik serta bertujuan untuk mengurangi pengangguran, maka memungkinkan pegawai melakukan KKN. KKN terjadi karena ketatnya kompetisi yang melibatkan banyak pegawai, sehingga bagi pegawai yang benar-benar berkompeten sangat kecil peluangnya menduduki suatu jabatan. KKN kemudian menjadi alternatif untuk memperoleh jabatan publik yang diingini. Di lain sisi, KKN terjadi antara masyarakat yang hendak memperoleh pelayanan cepat dengan aparatur yang memberi pelayanan. KKN dalam konteks ini tidak akan terjadi kalau peraturan dan prosedur pelayanan berjalan cepat, akurat dan bertanggungjawab. KKN juga tidak terjadi kalau aparatur birokrasi hidup berkecukupan dengan tidak mengandalkan penghasilannya pada pekerjaannya di sektor pelayanan publik, melainkan memperoleh penghasilan dari pekerjaan di sektor lain. Hal ini sebenarnya bisa terjadi bila aparat birokrasi mampu memaknai bahwa pekerjaan di sektor pelayanan publik adalah dalam rangka melayani kebutuhan dan kepentingan masyarakat, bukan untuk memperoleh keuntungan finansial.

Berbeda dengan organisasi bisnis yang kinerjanya dengan mudah bisa dilihat dari profitabilitas, yang diantaranya tercermin dari indeks harga saham di bursa, birokrasi pelayanan publik tidak memiliki tolok ukur yang jelas dan tidak mudah diperoleh informasinya oleh publik (Dwiyanto, 2001: 45). Indonesia adalah satu-satunya negara yang mempunyai struktur birokrasi terpanjang dan tergemuk di dunia. Panjangnya jalur birokrasi menurut Dwiyanto bisa dilihat dalam kepengurusan akta kelahiran. Aktivitasnya dimulai dengan membuat surat kelahiran dari rumah sakit, cek ke RT dan RW, lalu ke kelurahan, kecamatan dan terakhir ke Catatan Sipil. Di Kantor Catatan Sipil masih diminta saksi dua orang. Kemudian ke tingkat atas lagi, hampir semua departemen ikut terlibat dalam proses pengambilan kebijakan. Pelayanan terhadap publik menurut Dwiyanto menjadi sangat kompleks dan panjang karena kewenangan yang terbatas masih dibagi dalam kotak-kotak birokrasi. Akhirnya, investor harus menghadapi kotakkotak birokrasi, melewati banyak instansi untuk bisa masuk ke Indonesia, termasuk ke daerah-daerah (Kompas, 26/03/05). Walaupun belakangan banyak pemerintah daerah mengumbar slogan "pelayanan satu atap" atau "pelayanan satu pintu" tetapi tetap saja terdiri atas "banyak meja".

Ditinjau dari prinsip-prinsip dan proses bekerjanya organisasi agar mencapai tujuan secara optimal, birokrasi tidak berbeda dengan organisasi-organisasi lainnya, seperti organisasi perusahaan, organisasi sepakbola, organisasi kekuatan sosial politik, dan masih banyak lagi. Demikian juga dengan penentuan garis-garis komunikasi, garis-garis kewenangan dan garisgaris pertanggungjawaban, termasuk dalam 
Kebijakan Birokrasi Pelayanan Publik Berkualitas; Kisno Hadi

ilmu organisasi, semuanya sama saja (Gie, 2005). Namun persoalannya mengapa hanya lembaga birokrasi pela-yanan publik milik pemerintah saja yang dinilai buruk kualitasnya, sementara organisasi serupa yang berada di luar sistem pemerintah dinilai bagus dalam hal pelayanan.

Bagi penulis, sebagaimana pandangan kalangan pengamat kebijakan publik, persoalan tersebut adalah akibat warisan pemerintah kolonial Belanda dan pemerintahan militer Jepang yang sengaja menciptakan lembaga birokrasi untuk mengontrol perilaku masyarakat sekaligus untuk mempertahan kekuasaan. Dalam kerangka itu, pemerintah telah menyusun hierarki yang sangat kompleks dari pusat hingga ke tingkat kelurahan dan desa. Itu pun masih ditambah hingga ke tingkat RW dan RT. Selain itu, budaya birokrasi Indonesia yang diwarisi dari budaya feodalisme di masa lalu juga turut berpengaruh dalam menciptakan kondisi birokrasi pelayanan publik yang bermasalah itu. Di Korea Selatan, pejabat Eselon I direkrut dengan sistem terbuka. Siapa saja boleh mencalonkan diri dan dicalonkan sejauh kualifikasi yang disyaratkan terpenuhi. Penilaian dilakukan oleh komisi independen dengan proses perekrutan terbuka. Perekrutan yang terbuka juga memungkinkan adanya rotasi pegawai atau pejabat ke posisi di bidang lain yang sesuai dengan latar belakang ilmu dan keahlian. Namun di Indonesia, sampai detik ini masih dilakukan secara tertutup. Selain masyarakat tidak dapat mengawasi, hal ini juga berdampak buruk terhadap kinerja birokrasi. Akibatnya, secara internal belum ada solidaritas pegawai dalam memberikan pelayanan sosial secara adil dan merata (Kompas 26/03/05: 33).

Seperti apa pelayanan publik atau pelayanan sosial yang adil dan merata tersebut dipraktekkan. Novel Ali menyebut bahwa pelayanan sosial yang adil, merata serta sesuai dengan kehendak atau kebutuhan masyarakat harus sedikitnya mencakup 6 elemen penting untuk menjadi tolok ukurnya, yaitu (1) Mutu pelayanan dan jasa dan barang yang memadai; (2) Prosedur pelayanan yang mudah, lancar, cepat dan tepat; (3) Biaya pelayanan yang jelas dan memadai (murah); (4) Pemenuhan hak serta kewajiban pihak yang melayani, yang dilayani, yang dipahami oleh masing-masing pihak sebelumnya; (5) Kemudahan memperoleh informasi di seputar kuantitas dan kualitas pelayanan itu sendiri; dan (6) Tidak menimbulkan kesan diskriminasi pelayanan, dari berbagai obyek sasaran (Jur. IImu Sosiatri UGM, 1998).

Sementara Susetiawan menegaskan, bahwa pelayanan yang baik adalah pelayanan yang dilakukan dengan cepat oleh petugas yang melakukan pelayanan dan kualitas pelayanan dapat menjamin kebutuhan serta memuaskan pihak yang dilayani, maka hal ini sifatnya tergantung pada hubungan pada orang yang dilayani dan yang melayani (Jur. IImu Sosiatri UGM, 1998). Hingga sejauh ini sudahkah birokrasi di daerah-daerah yang dimotori pemimpin daerah menerapkan kebijakan-kebijakan pelayanan publik seperti konsep pemikiran tersebut di atas? Di bawah ini penulis mengajak pembaca untuk melihat salah satu praktek kebijakan pelayanan publik di suatu daerah di Kalimantan Tengah, yakni Kabupaten Pulang Pisau. Bagi penulis, Kabupaten Pulang Pisau cukup bisa menjadi contoh untuk mengukur implementasi pelayanan publik yang berkualitas.

\section{Pembahasan}

Kecamatan Kahayan Hilir adalah satu di antara beberapa kecamatan di Kabupaten Pulang Pisau yang menerapkan kebijakan yang sama dalam hal pelayanan publik, 
yakni berdasarkan Peraturan Daerah (Perda) Kabupaten Pulang Pisau No. 2 Tahun 2005 Tentang Pembentukan Organisasi dan Tata Kerja Perangkat Daerah Kabupaten Pulang Pisau, yang mana struktur tugasnya terdiri dari Camat, Sekcam, Kasi Pemerintahan, Kasi Tramtib dan Kasi Pembangunan. Praktek kebijakan birokrasi pelayanan publik di Kecamatan Kahayan Hilir juga dipraktekkan secara keseluruhan di kecamatan dalam wilayah administratib Kabupaten Pulang Pisau, sehingga juga menggambarkan proses pelayanan publik di Kabupaten Pulang Pisau secara keseluruhan. Luas wilayah Kecamatan Kahayan Hilir secara umum kurang lebih sekitar $360 \mathrm{~km}^{2}$ atau sekitar 36.000 hektar, yakni mencapai $4 \%$ dari luas wilayah Kabupaten Pulang Pisau. Dalam wilayah administratif Kecamatan Kahayan Hilir terdapat 2 (dua) kelurahan dan 6 (enam) desa serta 1 (satu) buah desa persiapan, yakni seperti yang terdapat dalam tabel 1 .
Sampai tahun 2008, berdasarkan data pada Pemerintah Kecamatan Kahayan Hilir yang diperoleh dari Badan Pusat Statistik Pemerintah Kabupaten Pulang Pisau bahwa jumlah penduduk Kecamatan Kahayan Hilir kurang lebih sekitar 24.892 jiwa, yakni terbagi atas 12.686 jiwa laki-laki dan 12.215 jiwa perempuan. Adapun tingkat pertumbuhan penduduk sebesar $0,46 \%$ per tahun dan kepadatan penduduk rata-rata 69 jiwa per $\mathrm{km}^{2}$ yang tersebar berdomisili pada 2 (dua) kelurahan dan 6 (enam) desa depinitif serta 1 (satu) desa persiapan yang ada di wilayah Kecamatan Kahayan Hilir. Sementara sumber mata pencaharian masyarakat pada umumnya sebagian besar adalah sebagai petani dan selebihnya sebagai pedagang, buruh, pegawai swasta, pegawai negeri sipil, anggota TNI dan anggota POLRI. Profesi sebagai petani tersebut adalah pertanian dalam arti luas yakni mencakup subsektor pertanian sendiri, perkebunan, peternakan, dan perikanan, dengan meman-

Tabel 1. Desa dan Kelurahan di Kecamatan Kahayan Hilir

\begin{tabular}{|c|c|c|c|}
\hline No. & Desa / Kelurahan & Jumlah RT & $\begin{array}{c}\text { Luas Wilayah } \\
\text { (Hektar) }\end{array}$ \\
\hline 1. & Kelurahan Pulang Pisau & 11 & 9.000 \\
\hline 2. & Kelurahan Kalawa & 10 & 4.800 \\
\hline 3. & Desa Gohong & 8 & 499 \\
\hline 4. & Desa Anjir Pulang Pisau & 6 & 5.501 \\
\hline 5 . & Desa Manteran I & 17 & 6.640 \\
\hline 6. & Desa Manteran II & 15 & 2.220 \\
\hline 7. & Desa Buntoi & 7 & 6.000 \\
\hline 8. & Desa Mintin & 8 & 560 \\
\hline \multirow[t]{2}{*}{9.} & $\begin{array}{l}\text { Desa Sukamaju (Desa Persiapan UPT } \\
\text { Anjir Pulang Pisau) }\end{array}$ & 13 & 780 \\
\hline & Jumlah & 95 & 36.000 \\
\hline
\end{tabular}

Sumber: Pemerintah Kecamatan Kahayan Hilir, 2008 
Kebijakan Birokrasi Pelayanan Publik Berkualitas; Kisno Hadi

faatkan lahan tanah pertanian seluas 58,7 $\%$ dari total luas wilayah Kecamatan Kahayan Hilir. Adapun persentase penggunaan lahan tanahnya seperti bagan dibawah ini.
Kecamatan Kahayan Hilir; (5) Kantor Urusan Agama Kecamatan Kahayan Hilir; (6) Pusat Kesehatan Masyarakat Pulang Pisau Kecamatan Kahayan Hilir; (7) Balai Penyuluh Pertanian (BPP) Kecamatan Kahayan

\footnotetext{
Bagan 1. Persentase Penggłnaann Tanàh di Kecamatan Kahayan Hilir

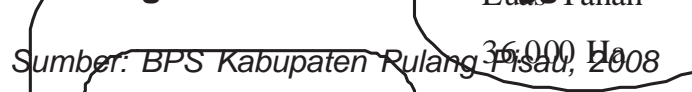
Lahan Pertanian

Hubungan tugas ke dalam diselenggarakan secaramaksimal dengan membina kerjasabsą, yang baik denфan unsur yang ada фi intern pemerintah kecamatan maupun dengan instansi lain secara vertikal yang beradiabdindakath: wilay h Kecamatan Kahфyan Hilir. Dasar pepyelenggaraan pemerintahannya sesuai Peraturan Pemerintsh (PP) No. G Tahun 1988 Tentang Penyeleangquraan Kordinasi dengan instansi-instansi vertikal. Adapun Dinas/

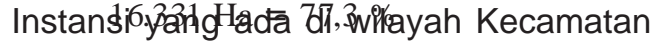
Kahayan Hilir ialah: (1) Polsek Kahayan Hilir; (2) Koramil 1011-15 Kahayan Hilir; (3) Cabang Dinas P, K dan P Kecamatan Kahayan Hilir; (4) Sektor Dinas Perhubungan

Non Pertanian

Hilir; (\$)8Bథtuqgas Mantri Tani Kahayan Hilir; (9) Petugas Statist k Kahayan Hilir; (10) SMUA-1TKahayan Hi ir; (11) SMK KARYA; (12) SMU PGRI; (13) SMPN -1 Kahayan Hilir; (14) SMPN - 2 Kahayan Hilir; (15) SMPN - 3 Kahayan Hilir; (16) SMPN - 4 Kahayan Hilir; (17) Kantor Pos Indonesia Kecamatan Kahayand Hilir ; (18) PLN Ranting Kahay Hilin; (19) PDAM Cabang Pulang Pisau; (20) BANK RAKYAT INDONESIA (BRI) Unit Pulang Pisau; (21) BANK PEMBANGUNAN KALTENG (BPK) Cab. Pembantu Pulang Pisau; (22) Depot Pertamina UPMS VI Pulang Pisau; (23) PELINDO III Pulang Pisau.
} 
UNISIA, Vol. XXXII No. 71 Juni 2009

\section{Jenis Pelayanan Publik yang diberikan}

Hal utama yang diberikan dalam pelayanan publik ini adalah dalam rangka memberi pelayanan yang maksimal kepada masyarakat. Semakin dekat keberadaan instansi pelayanan termaksud dengan masyarakat, maka diharapkan semakin cepat dan akurat pula pelayanan yang diberikan. Adapun jenis-jenis pelayanan publik yang diberikan ialah:

1. Pelayanan pembuatan KTP

2. Pelayanan pembuatan Kartu Keluarga (KK)

3. Pembuatan pengantar Akte Kelahiran

4. Pembuatan Akta Catatan Sipil

5. SPT (Surat Pernyataan Tanah)

6. Pembuatan Akte Jual Beli Tanah

7. Pembuatan Surat Keterangan Mutasi Penduduk

8. Pembuatan Rekomendasi ljin Mendirikan Bangunan (IMB)

9. Keterangan Kepegawaian

10. Surat Keterangan Berkelakuan Baik

11. Rekomendasi Usaha

12. Keterangan lain-lain.

Mulai tahun 2008 Pemerintah Kecamatan Kahayan Hilir telah menerapkan Kebijakan Pelayanan Satu Pintu (One Stop Service) dalam proses penyelenggaraan pelayanan publik, yakni telah dilaksanakan sejak 16 Juni 2008. Beberapa point jenis pelayanan publik seperti tersebut di atas menunjukkan sejumlah tersebutlah jenis pelayanan publik yang diberi dan dilaksanakan oleh aparatur pemerintah di Kecamatan Kahayan Hilir,sehingga sangat jelas dan mungkin ada pembedaan signifikan dengan jenis pelayanan yang diberikan oleh aparatur pemerintah di wilayah dan daerah lain. Dengan tersedianya jenis pelayanan satu pintu (one stop service) ini, dituntut mesti ada prosedur dalam proses pelaksanaan atau penyelenggaraannya. Sebab itu Pemerintah Kecamatan Kahayan Hilir menerapkan jenis prosedur yang mesti ditempuh masyarakat guna mengakses pelayanan yang diingini. Selain prosedur yang baku, pemerintah Kecamatan Kahayan Hilir juga membuka Layanan Pengaduan Masyarakat (LPM), baik melalui SMS maupun telepon yang sudah ditulis di setiap papan pengumuman kantor kecamatan dan kelurahan sehingga masyarakat boleh manyampaikan keluhannya.

Berdasar data sekunder yang didapat di lapangan, serta untuk lebih jelas dan terperinci, di bawah ini hendak menunjukkan seperti apa jenis pelayanan publik yang terdapat di Kecamatan Kahayan Hilir.

Melihat jenis pelayanan yang diberikan serta seperti apa prosedur mengaksesnya, diharapkan masyarakat bisa memperoleh pelayanan terbaik dan berkualitas dari aparatur pemerintahan daerah. Dengan tersedianya jenis-jenis pelayanan yang dibutuhkan serta transparansi dalam mengakses pelayanan yang diingini, maka masyarakat sebagai penerima layanan bisa terpuaskan. Terdapat 3 (tiga) jenis layanan yang paling banyak dipilih serta diakses oleh masyarakat dalam proses penyelenggaraan pelayanan publik ini, tiga jenis pelayanan termaksud ialah pembuatan KTP, pembuatan Kartu Keluarga dan pembuatan Pengantar Akte Kelahiran untuk menjadi rekomendasi mengurusnya di Kantor Dinas Kependudukan dan Catatan Sipil. Berikut prosedur mengakses pelayanan termaksud serta keterangan dari 150 orang penerima layanan yang menjadi sampel mengenai pelayanan publik di Kecamatan Kahayan Hilir ini yang sempat penulis minta informasinya. 
Kebijakan Birokrasi Pelayanan Publik Berkualitas; Kisno Hadi

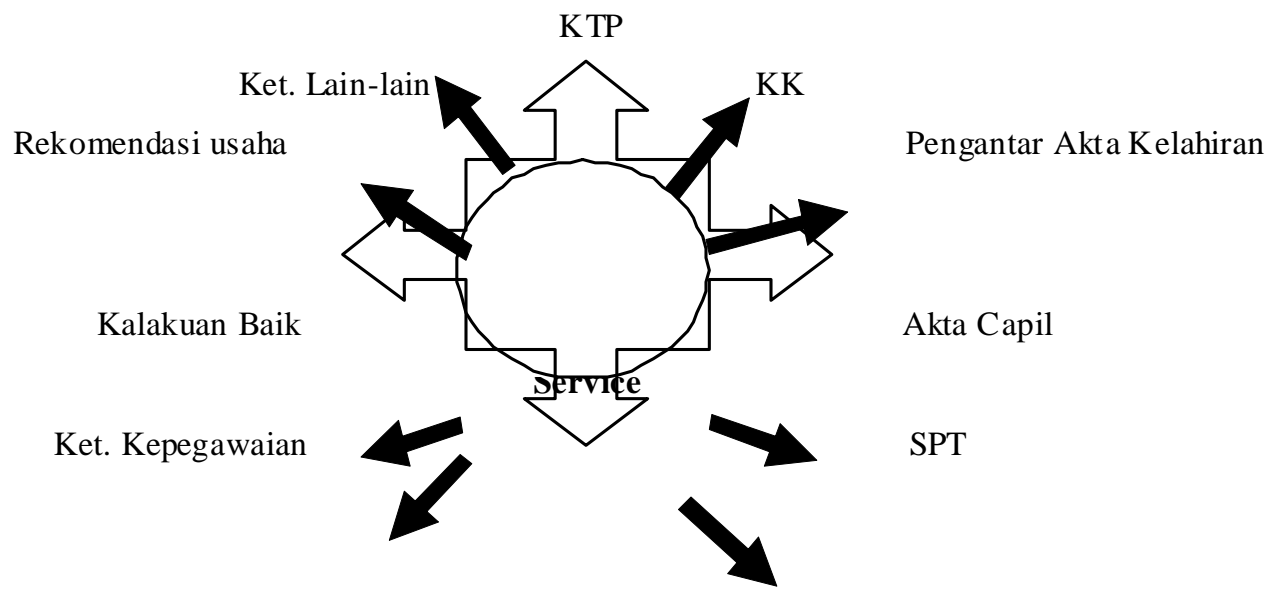

Rekomendasi IMB

Akta Jual Beli Tanah

Ket. Mutasi Penduduk

Bagan 2. Jenis Pelayanan

Sumber: Pemeritah Kecamatan Kahayan Hilir, 2008

Mulai tahap mekanisme mengaksesnya, sumber informasi dalam memperoleh pelayanan, ketidakadilan dalam pelayanan, kemudahan dalam proses pelayanan, kesesuaian proses penyelenggaraan pelayanan dengan ketentuan yang sudah diatur seperti pengumuman di papan pengumuman, praktek "uang pelicin" dalam proses pelayanan, hingga pendapat masyarakat mengenai biaya pelayanan, masing-masing informan yang ditemui di lapangan memberi penilaian secara positif. Artinya, arah kebijakan birokrasi pelayanan publik seperti yang ditetapkan oleh Pemkab Pulang Pisau dan Kecamatan Kahayan Hilir khususnya cukup memberi kepuasan kepada masyarakat. Selain itu, pelayananpelayanan yang diberikan juga memberi kecerdasan dan pencerahan kepada masyarakat, karena informasi yang diberikan sangat transparan sehingga tergantung kemauan masyarakat itu sendiri untuk mengaksesnya secara cermat. Tambah lagi pusat pengaduan pelayanan melalui SMS maupun telepon yang disediakan di pusat informasi pelayanan publik yang langsung terhubung dengan Camat dan Bupati menurut kebanyakan informan cukup membantu untuk melaporkan keluhankeluhan masyarakat berkaitan dengan pelayanan yang diterima.

Bagi sebagian masyarakat, prosedur yang dilakukan oleh Pemerintah Kabupaten Pulang Pisau khususnya Pemerintah Kecamatan Kahayan Hilir dalam melayani 24.892 jiwa masyarakatnya seperti yang diterangkan di atas adalah sebuah kebijakan yang cukup mengedepankan kepentingankepentingan masyarakat, yakni dalam rangka menciptakan birokrasi pelayan publik berkualitas. Kondisi tersebut terjadi karena: 
UNISIA, Vol. XXXII No. 71 Juni 2009

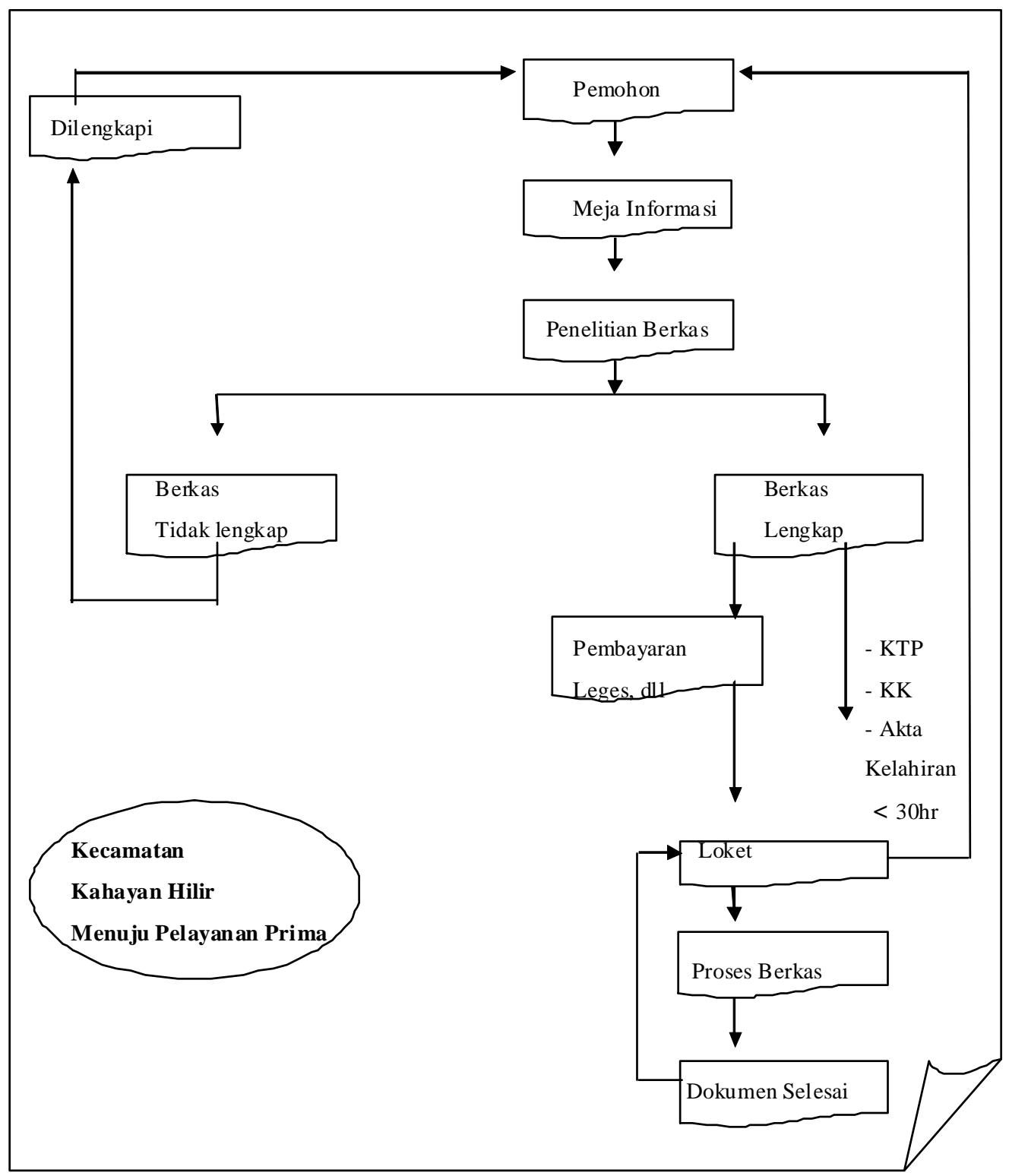

Sumber: Pemerintah Kecamatan Kahayan Hilir, 2008

Bagan 3. Prosedur Pelayanan Publik Satu Pintu 
Kebijakan Birokrasi Pelayanan Publik Berkualitas; Kisno Hadi

Tabel 2. Jenis Pelayanan Publik yang diterima

\begin{tabular}{|l|c|c|c|c|}
\hline \multicolumn{1}{|c|}{ Jenis Layanan } & Pernah & $\%$ & $\begin{array}{c}\text { Tidak } \\
\text { Pernah }\end{array}$ & $\%$ \\
\hline KTP & 147 & 98,0 & 3 & 2,0 \\
Kartu Keluarga & 122 & 81,3 & 28 & 18,7 \\
Pengantar Akta Kelahiran & 129 & 86,0 & 21 & 14,0 \\
Akta Catatan Sipil & 68 & 42,7 & 86 & 57,3 \\
SPT & 28 & 18,7 & 122 & 81,3 \\
Akta Jual Beli Tanah & 75 & 50,0 & 75 & 50,0 \\
Ket. Mutasi Penduduk & 37 & 24,7 & 113 & 75,3 \\
Rekomendasi IMB & 35 & 23,3 & 115 & 76,7 \\
Keterangan Kepegawaian & 70 & 46,7 & 80 & 53,3 \\
Kelakuan Baik & 68 & 45,3 & 82 & 54,7 \\
Rekomendasi Usaha & 44 & 29,3 & 106 & 70,7 \\
Keterangan Lain-Lain & 5 & 3,3 & 145 & 96,7 \\
\hline
\end{tabular}

Sumber: Data Sekunder Pemerintah Kecamatan Kahayan Hilir dan Data Primer Penulis, 2008

Pertama, pelayanan publik yang diberikan dimulai dari unit pelayanan terkecil yang memang paling dekat dengan keberadaan keseharian masyarakat; Kedua, meski harus dibuktikan dengan penelitian lebih lanjut, kuat dugaan penulis bahwa kondisi tersebut tidak lepas dari kebijakan Bupati Kabupaten Pulang Pisau (dua kali periode; 2002-2008 dan 2008-2013) yang berasal dari Partai Golkar dimana kebijakannya didukung oleh segenap aparat birokrasi hingga ke tataran unit pemerintahan terkecil, termasuk juga mendapat dukungan dari DPRD Kabupaten Pulang Pisau yang mayoritas diduduki oleh Partai Golkar pada Pemilu 2004; Ketiga, kebijakan tersebut juga tidak lepas dari karakter kuat dan tingginya integritas Pak Bupati dalam memimpin aparat birokrasi di Kabupaten Pulang Pisau sehingga hampir semua unit pemerintahan mendukung setiap kebijakan yang ditetapkan, termasuk kebijakan birokrasi pelayanan publik;

Keempat, dari hasil wawancara lepas dengan beberapa orang informan di lapangan, memperlihatkan bahwa hampir semua informan mengatakan sikap mendukung dengan pelayanan yang mereka dapatkan dari pemerintah Kecamatan Kahayan Hilir serta berharap pelayanan tersebut dapat dipertahankan bahkan terus bisa meningkat ke arah pelayanan gratis; Kelima, faktor kepemimpinan baik Camat maupun Bupati yang merupakan representasi masyarakat lokal sebagai "putera daerah" dirasa sangat membantu dalam memahami karakter, budaya dan kebutuhan masyarakat setempat, sehingga kebutuhan masyarakat menjadi perhatian serius untuk 
diutamakan. Oleh sebab itu, tidak mengherankan apabila masyarakat lokal menghendaki pemimpin mereka adalah "putera-puteri daerah" sendiri, karena memang "putera-puteri daerah" ini adalah representasi masyarakat yang mengerti kebutuhan-kebutuhan masyarakat lokal.

\section{Penutup}

Tulisan ini merupakan buah dari pengamatan awal penulis terhadap praktek birokrasi pemerintah daerah terutama yang dipraktekkan oleh unit terkecil lembaga birokrasi dalam hal pelayanan publik. Pelajaran yang dapat dipetik dari pengamatan awal ini paling tidak pertama, memberi pencerahan kepada kita bahwa kebijakan birokrasi pelayanan publik yang berbasis pada kepentingan masyarakat yang ditelorkan oleh kepemimpinan politik dan kepemimpinan pemerintahan yang berkarakter kuat serta pemimpin yang menjadi representasi masyarakat ternyata lebih mudah didukung baik oleh aparat birokrasi maupun masyarakat di areal pelayanan lembaga birokrasi itu berlangsung; kedua, kebijakan pengelolaan pemerintahan yang berangkat dari kebutuhan-kebutuhan masyarakat, nampaknya tidak mengalami hambatan berarti dalam hal implementasi, sehingga orientasi menuju birokrasi pelayanan publik berkualitas bisa terealisasi;

Ketiga, birokrasi pelayanan publik berkualitas niscaya bisa membuahkan pembangunan yang betul-betul bisa dinikmati oleh masyarakat, diantaranya masyarakat bisa berkarya untuk berpartisipasi mendorong kemajuannya. Dalam kondisi seperti itu, pelayanan birokrasi pemerintah diharapkan dapat memicu kehadiran investasi di sektor riil untuk memajukan perekonomian daerah; dan keempat; untuk menciptakan pelayanan birokrasi berkualitas mesti ada komitmen kuat pemimpin daerah beserta segenap stakeholders di daerah yang dapat dilakukan mulai dari mereorientasi misi pelayanan, mengubah kultur pelayanan, menciptakan pendidikan berpola pelayanan, memilih pemimpin politik berkultur pelayanan, kontrol yang kuat dari masyarakat sipil, serta menciptakan citra birokrasi pemerintah bukan sebagai tempat mencari nafkah melainkan sebagai sarana memberi pelayanan.

Pelayanan birokrasi berkualitas di daerah adalah sebuah kebutuhan mutlak yang tidak bisa ditawar lagi, dan harus segera direspon oleh setiap pemerintah daerah. Tujuan pemberian pelayanan publik berkualitas adalah semata untuk: pertama, mendekatkan keberadaan pemerintah (negara) kepada masyarakat; kedua, menciptakan kepercayaan masyarakat terhadap aparatur dan lembaga pemerintah daerah; ketiga, secara tidak langsung memberikan pendidikan politik kepada masyarakat tentang pelayanan publik berkualitas; keempat; memberikan rasa tanggung jawab bagi masyarakat agar turut serta mengawasi kinerja aparatur birokrasi; dan kelima, memaksimalkan fungsi pelayanan publik sebagai salah satu entitas pemerintahan daerah.

\section{Daftar Pustaka}

Antlov, Hans. 2004. "Kata Pengantar", dalam Gregorius Sahdan, Jalan Transisi Demokrasi Pasca Soeharto. Yogyakarta: Pondok Edukasi.

Dwiyanto, Agus. 2001. Reformasi Birokrasi Publik di Indonesia. Yogyakarta: Pusat Studi Kependudukan dan Kebijakan UGM.

Badan Administrasi Kepegawaian Negara. Harian Umum Kompas, 26 Maret 2005. 
Kebijakan Birokrasi Pelayanan Publik Berkualitas; Kisno Hadi

Bappenas. 2007. Pengembangan Ekonomi Daerah dan Sinergi Kebijakan Investasi Pusat-Daerah. Jakarta: Ringkasan Eksekutif Bappenas.

Gie, Kwik Gian, 2005. "Audit dan Penataan Kembali Organisasi Birokrasi”. Opini Harian Umum Kompas, 26 Maret.

Maddick, Henry. 2003. Desentralisasi dalam Praktek. Yogyakarta: Pustaka Kendi.

Ma'ruf, Muhammad.2006. "Meningkatkan Kualitas Pelayanan Publik" dalam Majalah Media Praja Vol. 1, No. 06, 16-30 April.

Rasyid, Ryass. 2007. Makna Pemerintahan: Tinjauan Dari Segi Etika dan Kepemimpinan. Jakarta: PT. Yarsif Watampone.

Rose-Ackerman, Susan. 2006. Korupsi dan Pemerintahan: Sebab, Akibat dan Reformasi. Jakarta: Pustaka Sinar Harapan.

Syafiie, Inu Kencana, Tandjung dan Modoeng. 1999. IImu Administrasi Publik. Jakarta: Rineka Cipta.
Jurusan Ilmu Sosiatri Fisipol UGM. 1998. Orientasi Pembangunan Masyarakat Desa Menyongsong Abad 21. Yogyakarta: Aditya Media.

Sumber-Sumber Lain:

Naskah Paparan Camat Kahayan Hilir dalam acara Kunjungan Kerja Bupati Pulang Pisau di Kecamatan Kahayan Hilir, tanggal 29 November 2008.

Naskah Profil Kecamatan Kahayan Hilir, 2008.

Perda Kabupaten Pulang Pisau No. 2 Tahun 2005 Tentang Pembentukan Organisasi dan Tata Kerja Perangkat Daerah Kabupaten Pulang Pisau.

BPS Kabupaten Pulang Pisau, 2008.

Data primer hasil interview November 2008 di Kecamatan Kahayan Hilir.

Kompas, 26 Maret 2005. 